\title{
Oil Price and Firm Level Equity Return: A Panel Approach
}

\author{
Suleman Sarwar* \\ School of Economics, Shandong University, \\ Jinan. PR China, \\ e-mail: ch.sulemansarwar@gmail.com
}

\author{
Chen WEI \\ School of Economics, Shandong University, \\ Jinan. PR China
}

\begin{abstract}
The study investigates the impact of oil prices on firm level equity return in case of Pakistan over the period 1998-2014, as this relationship is neglected by the previous literature. By using the panel data estimation, the results of full sample indicate significant positive effect of oil price changes on firm equity returns in the same period, whereas, the lagged oil price changes have significant negative effect on firms' equity return. Moreover, the industry level analysis also confirms the similar findings; results indicate significant positive impact of oil price on firms' equity return in full sample, textile, chemical and miscellaneous industry, while the lagged oil prices change negatively affect the stock returns of full sample and all the industries except tobacco, jute and vanaspati industries. The study confirms that rise in oil price transfer a positive signal in the stock market that boosts the firm-level equity return in Pakistan. In contrast to the negative shocks, the stock returns are significantly affected by the positive oil price shocks.
\end{abstract}

\section{Keywords- Oil price; Firm level return; Pakistan.}

\section{INTRODUCTION}

In the period of oil crisis, the connection between oil price variations and macroeconomic factors has attained substantial consideration among academic scholars. Oil is the main source of energy in modern era that supports the economic growth, industrial production and other factors. From last few decades, the oil price fluctuations have affected the growth process of developing and developed economies. Although the effect varies, from country to country, due to different monetary policy, oil taxes, industrial infrastructure and oil dependence. Most developed oil importing countries impose high taxes on oil to fulfill economic requirement; such high tax ratio prevent them from oil price fluctuations by adjusting the tax rate. Whereas, developing countries impose fewer taxes on oil to support their industries but potentially weak to hedge such oil price shocks. (Hamilton J. D., 1983; Hamilton J. D., 1985; Mork K. A., 1989)) prove that oil price adeversely effect economic growth.(Chang, Jha, Fernandez, \& Jam'an, 2011)suggest that oil shocks varies for oil exporting and importing countries. They also suggested higher oil price volatility will dampen macro-economic activities of oil importing countries due to more oil requirement.

A large number of studies also investigated the relationship between macroeconomic variables and stock return in developing and developed countries (Haque \& Sarwar, 2012; Kwon \& Shin, 1999; Mukherjee \& Naka, 1995; Bailey \& Chung, 1996; Johnson, Boone, Breach, \&
Friedman, 2000; Mireku, Sarkodie, \& Poku, 2013; Garba, 2014). (Haque \& Sarwar, 2012; Kwon \& Shin, 1999; Mukherjee \& Naka, 1995)report the significance relationship between macroeconomic factors and stock return. Whereas, number of researches reported the inconclusive role of macroeconomic variables to determine the stock returns. (Garba, 2014) examine the impact of inflation, interest rate, exchange rate and gross national income on common stock return of Nigerian manufacturing firms; the results reported the insignificance of all macroeconomic variables to determine stock return. (Mireku, Sarkodie, \& Poku, 2013)investigate the effect of inflation, exchange rate and interest rate on Ghana stock price movement and concluded low significance of these macroeconomic variables. (Johnson, Boone, Breach, \& Friedman, 2000) report the insignificance of macroeconomic factors to determine the stock returns of 25 emerging economies. (Bailey \& Chung, 1996).

Recently, researchers in great number focus the relation of oil price fluctuations on stock market returns especially sector-wise. The reaction of oil returns vary from oilintensive and less oil-intensive sectors, the oil return respond differently across heterogeneous sectors (Arouri, Does crude oil move stock markets in Europe? A sector investigation, 2011; Degiannakis, Filis, \& Floros, 2013; Elyasiani, Mansur, \& Odusami, 2011; Moya-Martínez, Ferrer-Lapeña, \& Escribano-Sotosc, 2014). (Elyasiani, Mansur, \& Odusami, 2011)confirm oil-user and financial sector show an unfavorable trend during oil price shocks, while favorable to oil related sector. (Moya-Martínez, Ferrer-Lapeña, \& Escribano-Sotosc, 2014)report that oil price has insignificant role in Spanish stock return whereas (Caporale, Ali, \& Spagnolo, 2015; Huang, An, Gaoa, \& Huanga, 2015; Fan \& Jahan-Parvar, 2012) validate significant relationship among oil price and industry-level returns.(Degiannakis, Filis, \& Floros, 2013)find asymmetry relationship between oil price and European industry level returns.

Overall, the above literature concludes the inability of CAPM, TFM and macroeconomic variables to predict the stock return. Forsuch reasons, we limit this study to examine the role oil return, lagged oil return and oil price volatility to determine the stock returns in case of Pakistan. The proposed model of this study is similar to the model of (Fan \& JahanParvar, 2012; Demirer, Jategaonkar, \& Khalifa, 2015)by limiting the lags and enhancing the oil price volatility.

The study investigates impact of oil price fluctuations on individual firm stock returns by using panel data econometric technique. The firms listed in Karachi stock exchange with available data from 1999-2011 has been included for the analysis. The study involves 396 non-financial firms which 
are further categorized into 12 industries for the research. There are three main objective of the study which are: Firstly: the paper analyzes the impact of oil return, lagged oil price and oil price volatility on stock returns at firm level. Secondly, the paper justifies the oil return lagged oil price and oil price volatility impact on stock returns of different sectors. Lastly, the study examines the reaction of positive and negative oil price shocks on stock returns.

The subsequent part of paper provides literature review followed by data and methodology used to test the relation between oil price and stock returns. Finally, results achieved by the panel data estimation which completes the paper providing concluding remarks.

\section{DATA AND METHODOLOGY}

The study uses annual data of Pakistan taken from business recorder, state bank of Pakistan yearly report, and EIA database. The natural logarithm of crude oil WTI spot price (US dollars per barrel) is used as a proxy of oil price. Firm-level equity returns is calculated by taking natural logarithm of share's closing price at time t divide by share's closing time of closing price at time $\mathrm{t}-1$. The study utilizes the yearly panel data of all non-financial listed firms from 1998 to 2014; due to non-oil dependence we excluded the financial firms from this study. Furthermore, the firms having no data of last three years, the firms merged or acquired during study period or delisted from Karachi stock exchange are eliminated from this study. The final data set contains the panel of 397 non-financial listed firms of Pakistan. The panel estimation model of the current study examines the effect of current oil price and lagged oil price on firm level stock returns. The model is as follows:

$$
E R_{i t}=\beta_{i}+\gamma_{0} O P_{t}+\gamma_{1} O P_{t-1}+\gamma_{2} O P_{\text {volatility }}+\varepsilon_{i t}
$$

Where $\mathrm{ER}_{\mathrm{it}}$ is firm stock returns and is calculated by [ln $(\mathrm{Pt} / \mathrm{Pt}-1)]$; $\mathrm{OP}_{\mathrm{t}}$ represents the current oil return at time $(t) 1$ which is estimated by $\left[\ln \left(\mathrm{OP}_{t} / \mathrm{OP}_{t^{-1}}\right)\right]$; OPt-1 is the lagged oil price at time (t-1); OPvolatilityt presents the oil price volatility $^{2}$. We take the natural logarithm of current and lagged oil prices to standardize the variables. Firstly, we analyze the general results of full sample; secondly, we extend our study from general to specific by investigating the impact of oil returns on sector vise stock returns. The study follows (Mork K. A., 1989; Mork K. , 1994) studies to calculate the positive and negative oil prices; if oil price growth is positive it considered positive shock, otherwise negative shock.

\section{EMPIRICAL RESULTS: DISCUSSION AND COMPARISON WITH PREVIOUS STUDIES}

\section{A. Descriptive}

The descriptive statistics of the firm stock return (ER) and oil price (OP) is presented in Table-1; number of observation, mean, standard deviation, minimum value, maximum value, skewness and kurtosis are given in descriptive table. ER and OP have 6326 and 6749 number of observations, respectively. ER having the mean value 0.029 with standard deviation 0.452 , while the minimum and maximum values are -5.623 and 8.396 , respectively, this represents that there is no evidence of outlier in the given variable. The mean of OP is 3.915 with standard deviation 0.615 , the minimum and maximum values also present no significant outlier in OP. The ER and OP are positively skewed and show leptokurtic distribution.

TABLE I. DESCRIPTIVE STATISTICS

\begin{tabular}{ccc}
\hline & $\boldsymbol{E R}$ & $\boldsymbol{O P}$ \\
\hline \hline No. of Obs & 6326 & 6749 \\
\hline Mean & 0.029 & 3.915 \\
\hline S.D & 0.452 & 0.615 \\
\hline Max & 8.396 & 4.602 \\
\hline Min & -5.623 & 2.669 \\
\hline Skewness & 0.602 & -0.521 \\
\hline Kurtosis & 33.121 & 1.932 \\
\hline
\end{tabular}

B. Regression Analysis

Table 2 presents the panel estimation results of full sample that includes textile, chemical, engineering, sugar, paper and board, cement, fuel and energy, transport and communication, tobacco, jute, vanaspati and miscellaneous industries over the yearly data from 1998 to 2014 . The data suffers the issues of cross-sectional dependence ${ }^{3}$ and heteroskedasticity ${ }^{4}$. Generalized Method of Momentum (GMM) is the best fit for the econometric analysis to examine the effect of oil variables on stock returns.

The full sample results indicate the significant positive effect of oil price changes on firm equity returns on the same period; the result indicates that the change in oil prices is due to the demand side pressure, the price increases because of oil demand by the Pakistani industries to enhance their operations which also provides positive signal in the stock market and investors increase the trading of such stocks. The result of current oil return is inline with (Gupta \&Modise, 2013; Degiannakis, Filis, \&Floros, 2013). The positive significant effect of oil return on fuel and energy sector is proved by (Elyasiani, Mansur, \&Odusami, 2011; Narayan \& Sharma, 2011; Arouri, 2011).

\footnotetext{
${ }^{3}$ Pesaran's test of cross sectional independence $=97.282, \mathrm{Pr}=0.0000$

${ }^{4}$ Wooldridge test for autocorrelation in panel data (Prob $>\mathrm{F}=0.0000$ )
}

\footnotetext{
${ }^{1}$ (Arouri, Lahiani, \& Nguyen, Return and volatility transmission between world oil prices and stock markets of the GCC countries, 2011) method is used to calculate the oil return

${ }^{2}$ Oil price volatility is used by GARCH method.
} 
TABLE II. REGRESSION ANALYSIS

\begin{tabular}{cccc}
\hline & OP $_{t}$ & OP $_{t-1}$ & OP Vol $_{\boldsymbol{t}}$ \\
\hline \hline Full Sample Result & $0.2548^{*}$ & $-0.4957^{*}$ & $-27.5794^{*}$ \\
Textile & $0.3553^{*}$ & $-0.4966^{*}$ & $-24.7585^{*}$ \\
Chemical & $0.3565^{*}$ & $-0.4938^{*}$ & $-15.0067^{*}$ \\
Engineering & -0.0447 & $-0.4154^{*}$ & $-53.20667^{*}$ \\
Sugar & 0.1165 & $-0.3053^{*}$ & $-13.848^{*}$ \\
Paper \& Board & 0.3494 & $-1.0431^{*}$ & -20.0966 \\
Cement & $0.3076^{*}$ & $-0.6043^{*}$ & $-54.2864^{*}$ \\
Fuel \& Energy & $0.3111^{*}$ & $-0.5321^{*}$ & $-16.4008^{* *}$ \\
Transport \& Communication & 0.1826 & $-0.4868^{*}$ & $-69.1812^{*}$ \\
Tobacco & 0.1046 & -0.297 & $-34.0404^{* *}$ \\
Jute & -0.0758 & -0.1291 & $-43.1765^{*}$ \\
Vanaspati & 0.1614 & -0.367 & -27.4461 \\
Misc & $0.1616^{* *}$ & $-0.4589^{*}$ & $-31.5276^{*}$ \\
\hline
\end{tabular}

*** indicates $5 \%$ and $10 \%$ level of significance respectively

On the other side, there is a significant negative relationship find between oil price change of previous year and current equity returns and is similar with (Fan \&JahanParvar, 2012); the expected reason for the lagged negative relationship can be the increase in production cost. The continues rise in oil prices push the production cost which in return increase the product prices, such inflationary pressure on the economy decline the purchasing power of the consumers. After that firms decrease their production that adversely hit the financial earning of the company and transfer a negative signal in the stock markets. Resultantly, the investors decrease the trading in stocks which reduce the stock returns in Pakistani stock markets.

The volatility of oil prices creates uncertainty and has significant effects on growth and investor's confidence (Masih, Peters, \& Mello, 2011). The oil importing countries are likely to be more effected by such oil price volatility, especially where infrastructure and policy makings are week. The finding of full sample confirms a significant negative effect of oil price volatility on stock returns; the high oil price volatility tend to decrease the stock returns which is parallel with (Kang, Ratti, \& Yoon, 2015; Diaz, Molero, \&Gracia, 2016). The above results indicate that oil price volatility is the most significant factor to determine the stock returns in Pakistan.

\section{Industry Analysis:}

Results indicate significant positive impact of oil price on firms' equity return in textile, chemical, cement, fuel \& energy and miscellaneous industry, while engineering, sugar, paper \& board, Transportation \& communication, tobacco, jute and vanaspati are insignificant. The significant positive relation indicates that oil price rise do not badly hurt the Pakistani industrial infrastructure and the stocks on aggregate level and industrial level absorb the oil price shocks.

During the study period the oil prices continuously increase in global market, but the industrial infrastructure of Pakistan also progressed from 1998 to 2008, but after that the industries gradually closed their operations, not because of the oil prices, bad policies, corruption, and energy crisis. On the other side, when the oil price declines, the Pakistani government does not shift the advantage to the industry level and the individuals; the cost of transportation, cost of raw material, and cost of electricity remains the same. As a consequence, the declines in oil prices either insignificantly or adversely affect the industries and the stocks. The sharp decline in oil prices affect the oil exporting economies and the import of such countries shrink down, as a result, the economies with industrial infrastructure which relies on exports also badly affected due to decline in their exports. Such decline in exports reduces the firm's profit which transmits a negative signal in the stock markets.

Furthermore, the lagged oil prices negatively affect the stock returns of full sample and all the industries except tobacco, vanaspati and miscellaneous industries. The reason for this negative relation is the product cost aspect. The constant rise in oil price creates inflation and destabilizes the industrial production and financial earnings that negatively affect stock returns. The result of textile industry is consistent with (Arshad\& Bashir, 2015; Nandha\& Faff, 2008), the main reason of oil dependency of textile sector is that it heavily relies on fuel for their production operation and consumes $20 \%$ of total fuel energy consumed by Pakistani industries (International Resources Group, 2011). The insignificant relation of tobacco industry is due to the continues rise in tobacco products prices and demand every year in Pakistan which improves the financial earnings; the investors focus the fundamentals values of tobacco industry and know that it's independent from oil price shocks. 
Table 2 portray the overall results findings of oil price shocks on particular industries but unable to highlight the individual firms response. Furthermore, to extend the analysis, Table 3 presents the results of individual companies related to the same industries; the purpose is to analyze the response of firms stock return belongs to similar sector are identical due to the oil price shocks. This micro level approach further helps to individual firms to form an appropriate plan according to the response of oil price shocks.

TABLE III. INDIVIDUAL FIRM ANALYSIS

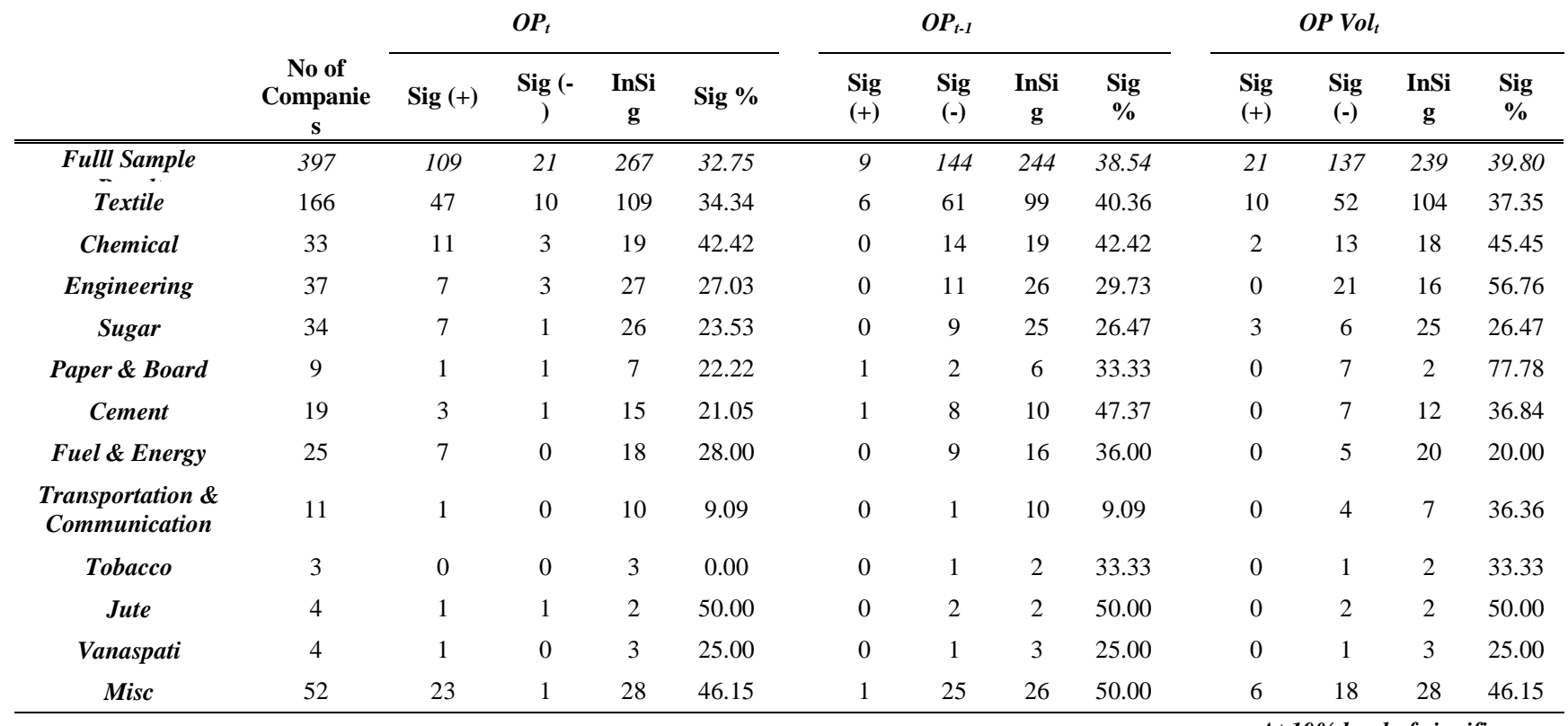

The results indicates, $32.75 \%$ companies respond to the oil price shocks in the current period; among them 109 firms have positive influence, while 21 firms have reported significant negative relationship with oil price shocks. Oil and gas sector presents $28 \%$ firm's stock returns lead to increase in the current period due to the oil price shocks; the given result point out that oil and gas is the basic raw material to run the production operation, leading to the fact that rise in oil prices generate a greater margin of profit, which helps to attract the stock market investors. The results are similar to (Teixeira, Madaleno, \& Vieira, 2016; Arouri, 2011; Ramos \& Veiga, 2011; Nandha \& Faff, 2008). Textile, sugar, vanaspati and tobacco industries belong to consumer goods sector; most of the firm's stock return has positive relationship with current oil price shocks, except tobacco industry. Tobacco industry consists of three companies in the study, none of the stocks influence by the oil price shocks in Pakistan. The main reason for the insignificance of tobacco companies are the inelasticity of demand for tobacco products, these finding meets the study results of (Teixeira, Madaleno, \& Vieira, 2016; Arouri, 2011; Mohanty, Nandha, Turkistanic, \& Alaitanic, 2011). Basic material sector consists of paper \& board, jute and chemical industries; the firm's stock return belongs to this sector reacts significant positively to oil price shocks, the given results are in line with (Arouri, 2011) but differ from those of (Narayan \& Sharma, 2011) who finds a significant negative relationship.
However, 28 firms of basic material sector do not respond to movement in oil prices.

The industry sector in Pakistan is the one that proves to be mix evidence, while most of the firms have reported insignificant association with oil price shocks, the result resembles those of (Teixeira, Madaleno, \& Vieira, 2016; Arouri, 2011). Ten firms present the significant positive association with oil price shocks which contradict with (Narayan \& Sharma, 2011) who conclude a significant negative association. All the studied firms, except one firm, in Telecommunication sector is insignificant to the movement of oil prices in case of Pakistan. The present results for telecommunication sector are consistent with (Teixeira, Madaleno, \& Vieira, 2016; Nandha \& Faff, 2008). These findings also endorse the results of transportation and communication present in table 2. Miscellaneous sector consists of small firms belongs to different industries 5 . $46.15 \%$ firms of this sector reported significant to oil price shocks, 23 out of 24 companies have testified positive relationship with oil price shocks.

Remaining columns of table 3 represent the lagged oil price and oil price volatility effect in firm's stock returns. $38.54 \%$ firms are significantly affected by the movement in oil prices in the upcoming periods; 144 firms have positive relationship with such oil price shocks while 9 firms reported

\footnotetext{
${ }^{5}$ Due to the less number of firms we combine them in one head for better
} statistical analysis 
negative association. This positive result validates the outcome of lagged oil price given in table 2 . Similarly, the volatility in oil price presents significant negative association in 137 firms and validates the negative relationship between oil prices and firm's stock return.

\section{Asymmetry analysis}

The oil price shocks affect the economic activities and stock return are non-linear and asymmetric that be influenced by demand side shock or supply side shock, and also the economic situation of countries (Jiménez-Rodríguez, 2008; Kilian L. , 2009; Kilian\& Park, 2009; Narayan \& Gupta, 2015).

TABLE IV. ASYMMETRY ANALYSIS

\begin{tabular}{|c|c|c|c|c|}
\hline & \multicolumn{2}{|c|}{ Negative Shock } & \multicolumn{2}{|c|}{ Positive Shock } \\
\hline & $O P_{t}$ & $O P_{t-1}$ & $\boldsymbol{O P} \boldsymbol{P}_{t}$ & $O P_{t-1}$ \\
\hline Fulll Sample Result & $0.3883^{*}$ & $-0.3956^{*}$ & $0.5763^{*}$ & $-0.9874^{*}$ \\
\hline Textile & $0.3674^{*}$ & $-0.4442^{*}$ & $0.7412^{*}$ & $-1.1226^{* *}$ \\
\hline Chemical & $0.4314^{*}$ & $-0.3049^{*}$ & $0.6856^{*}$ & $-0.9861^{*}$ \\
\hline Engineering & 0.4391 & -0.2834 & $0.2369^{*}$ & $-0.7943^{*}$ \\
\hline Sugar & 0.0207 & -0.1969 & $0.4571^{* *}$ & $-0.7763^{*}$ \\
\hline Paper \& Board & -1.5594 & $-1.3873^{*}$ & $1.7241^{*}$ & $-2.6948^{*}$ \\
\hline Cement & 0.4427 & $-0.6984^{*}$ & $0.3570^{*}$ & $-0.7425^{*}$ \\
\hline Fuel \& Energy & 0.2386 & $-0.6486^{*}$ & $0.6169^{*}$ & $-0.9925^{*}$ \\
\hline Transport \& Communication & 0.0096 & -0.974 & 0.4701 & $-0.8545^{*}$ \\
\hline Tobacco & -0.7441 & 0.1704 & 0.5171 & $-0.7141^{*}$ \\
\hline Jute & 0.2218 & 0.1619 & 0.4286 & $-0.8832^{* *}$ \\
\hline Vanaspati & -0.3022 & -0.2356 & $0.8364^{*}$ & $-1.3062^{*}$ \\
\hline Misc & -0.0546 & $-0.3531^{*}$ & $0.2888^{*}$ & $-0.6262^{*}$ \\
\hline
\end{tabular}

*,** indicates $5 \%$ and $10 \%$ level of significance respectively

Table 4 reported the asymmetric results of oil price shocks. The negative shocks of oil prices documented insignificance of negative oil price shocks on Pakistani industries, except textile and chemical industry; the finding of (Mory, 1993; Mork K. , 1994) also reported the decreases in oil price have no significant effect on output. Whereas, lagged oil prices adversely affect the firm's stock returns in full sample, textile, chemical, paper \& board, cement, fuel \& energy sectors; the long term decrease in oil prices supports the manufacturing industries to reduce the production costs and strengthen the financial statement that provides a positive signal to the stock market.

Table 4 reported the results of positive oil price shocks on stock returns. In contrast to the negative shocks, the stock returns are significantly affected by the positive oil price shocks. The stock return of full sample, textile, chemical, engineering, sugar, paper \& board, cement, fuel and energy, vanaspati and misc industry explains a positive significant; similar results are reported by (Caporale, Ali, \&Spagnolo, 2015; Demirer, Jategaonkar, \&Khalifa, 2015). The increase in oil prices, during the study period, is caused by demand side shocks by the industries to enhance their operations which deliver an optimistic view to the investors for stock trading; these results are inline with (Narayan \& Sharma, 2011). The lagged oil prices reported that continues increase in oil prices adversely affects the stock returns; the rise in oil price over a period of time destabilizes the economy and industrial infrastructure which directly or indirectly hit the stock returns.

\section{CONCLUSION}

There is a huge body of literature that investigates how the oil price affects stock returns. An apparent research gap, however, present in this literature. Our approach is to concentrate on three specific issues. First, we examine the impact of oil prices on Pakistani firm returns, for the purpose we analyze the data of 397 listed firms over the period 19982014. The fixed effect method confirmed a significant positive relationship between oil prices and firm's equity return. Second, the study investigates whether the effect of the oil price on firm's equity return is the same for all industries; we confirm that it is not. The effect of the oil prices on firm level equity returns is industry-specific. We divide firms into 12 industries and unravel that while for the 
most of the industries, a rise in the oil price generally increases firms' equity return; tobacco, jute and vanaspati are the only industries that prove insignificant. Finally, we examine whether the oil price affects firms' level equity return with lag, and whether such an association is industry specific. The results find that lagged oil prices affect adversely in most of the industries, except tobacco, vanaspati and miscellaneous industries.

The significant positive relation indicates that oil price rise do not adversely affect the Pakistani industrial infrastructure and the stocks on aggregate level and industrial level absorb the oil price shocks. The result indicates that the change in oil price can be due to the demand side pressure during the study period, the price increases because of oil demand by the Pakistani industries to enhance their operations which also provides positive signal in the stock market and investors increase the trading of such stocks. On the other side, when the oil price declines, the Pakistani government does not shift the advantage to the industry level and the individuals; the cost of transportation, cost of raw material, and cost of electricity remains the same. As a consequences, the decline in oil price either insignificant or adversely affect the industries and the stocks. The expected reason for the lagged negative relationship can be the increase in production cost. The continues rise in oil prices push the production cost which in turn increase the product prices, such inflationary pressure on the economy decline the purchasing power of the consumers. After that firms decrease their production that adversely hit the financial earning of the company and transfer a negative signal in the stock markets. According to the consequence, the investors decrease the trading in stocks which reduce the stock returns in Pakistani stock markets. The volatility of oil prices creates uncertainty and has significant effects on growth and investor's confidence (Masih, Peters, \& Mello, 2011). The oil importing countries are likely to be more effected by such oil price volatility, especially where infrastructure and policy makings are week. In contrast to the negative shocks, the stock returns are significantly affected by the positive oil price shocks.

In summarize; the rise in oil price transfer a positive signal in the stock market that boosts the firm level equity returns in Pakistan. The implication of the present study is multidimensional; firstly, as the industrial infrastructure is not capable enough to absorb the effect of oil prices for longer period of time, so the managers and policy maker should formulate sound industrial policies to mitigate the adverse impact of oil prices over longer period of time. Secondly, for the investors perspective, the positive relationship between oil price and firms equity return indicates that during the rise in oil prices the investors should buy the firm's stock to gain the higher capital gain, but should not hold them for longer period of time. Thirdly, financial managers can cope the risk of oil price fluctuations by implementing hedging activities. For further research, the study can be divided according to the pre-crisis, during-crisis and post-crisis period to analyze the effect of oil prices on industries.
Many questions remain unaddressed about the effect of oil price on stock returns due to unavailability of data before 1998. Karachi stock exchange is an emerging stock exchange that has different characteristics and operations, so, the results and findings are not applicable for developed stock exchanges. For further research, the study can be divided according to the pre-crisis, during-crisis and postcrisis period to analyze the effect of oil prices on industries.

\section{REFERENCES}

[1] Aggarwa, R., Akhigbe, A., \& Mohanty, S. (2012). Oil price shocks and transportation firm asset prices. Energy Economics, 34, 13701379.

[2] Aloui, C., Nguyen, D. K., \& Njeh, H. (2012). Assessing the impacts of oil price fluctuations on stock returns in emerging markets. Economic Modelling, 29(6), 2686-2695.

[3] Ansar, I., \& Asghar, N. (2013). The Impact of Oil prices on stock exchange and CPI in Pakistan. Journal of Business and Management, 7(6), 32-36.

[4] Arouri, M. E. $(2011,7)$. Does crude oil move stock markets in Europe? A sector investigation. Economic Modelling, 28(4), 1716-1725.

[5] Arouri, M. E., Lahiani, A., \& Nguyen, D. K. (2011). Return and volatility transmission between world oil prices and stock markets of the GCC countries. Economic Modelling, 28, 1815-1825.

[6] Arshad, R., \& Bashir, A. (2015). Impact of Oil and Gas Prices on Stock Returns: Evidence from Pakistan's Energy Intensive Industries. International Review of Social Sciences, 3(4), 156-168.

[7] Bailey, W., \& Chung, Y. (1996). Risk and return in the Philippine equity market: A multifactor exploration. Pacific-Basin Finance Journal, 4(2-3), 197-218.

[8] Bjomland, H. (2009). Bjørnland, H., 2009. Oil price shocks and stock market booms in an oil exporting country. Scott. J. Polit. Econ. 56, Scot. J. Polit. Econ, 56, 232-254.

[9] Black, F., \& Scholes, M. (1974). The effects of dividend yield and dividend policy on common stock prices and returns. Journal of Financial Economics, 1(1), 1-22.

[10] Caporale, G. M., Ali, F. M., \& Spagnolo, N. (2015). Oil price uncertainty and sectoral stock returns in China: A time-varying approach. China Economic Review, 34, 311-321.

[11] Chang, Y. C., Jha, K., Fernandez, K. M., \& Jam'an, N. F. (2011). Oil Price Fluctuations and Macroeconomic Performances in Asian and Oceanic Economies. working aper.

[12] Chiwanza, W., Gachira, W., Nkomo, D. J., \& Chikore, R. (2015). Zimbabwe Stock Exchange ("ZSE")'s Exposure to Global Crude Oil Price Volatility. British Journal of Economics, Management \& Trade, 6(1), 22-37.

[13] Cong, R.-G., Wei, Y.-M., Jiao, J.-L., \& Fan, Y. (2008). Relationships between oil price shocks and stock market: An empirical analysis from China. Energy Policy, 36(9), 3544-3553.

[14] Degiannakis, S., Filis, G., \& Floros, C. (2013, 10). Oil and stock returns: Evidence from European industrial sector indices in a timevarying environment. Journal of International Financial Markets, Institutions and Money, 26(C), 175-191.

[15] Demirer, R., Jategaonkar, S., \& Khalifa, A. (2015). Oil price risk exposure and the cross-section of stock returns: The case of net exporting countries. Energy Economics, 49, 132-140.

[16] Dhaoui, A., \& Khraief, N. (2014). Empirical Linkage between Oil Price and Stock Market Returns and Volatility: Evidence from International Developed Markets. Discussion Paper.

[17] Diaz, E. M., Molero, J. C., \& Gracia, F. P. (2016). Oil price volatility and stock returns in the G7 economies. Energy Economics, 54, 417430.

[18] Driesprong, G., Jacobsen, B., \& Maat, B. (2008). Striking oil: Another puzzle? Journal of Financial Economics, 89(2), 307-327. 
[19] Elyasiani, E., Mansur, I., \& Odusami, B. (2011, 9). Oil price shocks and industry stock returns. Energy Economics, 33(5), 966-974.

[20] Fama, E., \& French, K. (1992). The Cross-Section of Expected Stock Returns. The Journal of Finance, 47(2), 427-465.

[21] Fan, Q., \& Jahan-Parvar, M. R. (2012). U.S. industry-level returns and oil prices. International Review of Economics and Finance, 22, $112-128$.

[22] Garba, A. (2014). Impact of Macroeconomic Factors on Common Stock Returns: A Study of Listed Manufacturing Firms in Nigeria. European Journal of Business and Management, 6(13), 140-150.

[23] Gupta, R., \& Modise, M. (2013). Does the source of oil price shocks matter for South African stock returns? A structural VAR approach. Energy Economics, 40, 825-831.

[24] Hamilton, J. D. (1983). Oil and the Macroeconomy since World War II. Journal of Political Economy, 91(2), 228-248.

[25] Hamilton, J. D. (1985). Historical Causes of Postwar Oil Shocks and Recessions. Energy Journal, 6(1), 97-116.

[26] Hammoudeh, S., \& Aleisa, E. (2004). Dynamic Relationships among GCC Stock Markets and Nymex Oil Futures. Contemporary Economic Policy, 22(2), 250-269.

[27] Hammoudeh, S., \& Li, H. (2004). Risk-return relationships in oilsensitive stock markets. Finance Letters, 2(3), 10-15.

[28] Haque, A., \& Sarwar, S. (2012). Macro-Determinants of Stock Return in Pakistan. Middle-East Journal of Scientific Research, 12(4), 504510 .

[29] Huang, S., An, H., Gaoa, X., \& Huanga, X. (2015). Identifying the multiscale impacts of crude oil price shocks on the stock market in China at the sector level. Physica A, 434, 13-24.

[30] Jiménez-Rodríguez, R. (2008). The impact of oil price shocks: Evidence from the industries of six OECD countries. Energy Economics, 30(6), 3095-3108.

[31] Johnson, S., Boone, P., Breach, A., \& Friedman, E. (2000). Corporate governance in the Asian financial crisis. Journal of Financial Economics, 58(1-2), 141-186.

[32] Kang, W., Ratti, R., \& Yoon, K. H. (2015). The impact of oil price shocks on the stock market return and volatility relationship. Journal of International Financial Markets, Institutions \& Money, 34, 41-54.

[33] Kilian, L. (2009). Not all oil price shocks are alike: disentangling demand and supply shocks in the crude oil market. American Economic Review, 99(3), 1053-1069.

[34] Kilian, L., \& Park, C. (2009). The Impact Of Oil Price Shocks On The U.S. Stock Market. International Economic Review, 50(4), 12671287.

[35] Kwon, C., \& Shin, T. (1999). Cointegration and causality between macroeconomic variables and stock market returns. Global Finance Journal, 10(1), 71-81.

[36] Lintner, J. (1965). The valuation of risk assets and selection of risky investments in stock portfolios and capital budgets. The Review of Economics and Statistics, 47(1), 13-37.

[37] Masih, R., Peters, S., \& Mello, L. D. (2011). Oil price volatility and stock price fluctuations in an emerging market: Evidence from South Korea. Energy Economics, 33, 975-986.

[38] Miller, M. (2000). The History Of Finance: An Eyewitness Account. Journal of Applied Corporate Finance, 13(2), 8-14.
[39] Mireku, K., Sarkodie, K., \& Poku, K. (2013). Effect of Macroeconomic Factors on Stock Prices in Ghana: A Vector Error Correction Model Approach. International Journal of Academic Research in Accounting, Finance and Management Sciences, 3(2), 32-43.

[40] Mohanty, S., Nandha, M., Turkistanic, A., \& Alaitanic, M. (2011). Oil price movements and stock market returns: Evidence from Gulf Cooperation Council (GCC) countries. Global Finance Journal, 22(1), $42-55$.

[41] Mork, K. (1994). Business cycles and the oil market. The Energy Journal, 15, 15-38.

[42] Mork, K. A. $(1989,6)$. Oil and Macroeconomy When Prices Go Up and Down: An Extension of Hamilton's Results. Journal of Political Economy, 97(3), 740-744.

[43] Mory, J. (1993). Oil prices and economic activity: is the relationship symmetric? The Energy Journal, 14, 151-161.

[44] Moya-Martínez, P., Ferrer-Lapeña, R., \& Escribano-Sotosc, F. (2014, 2). Oil price risk in the Spanish stock market: An industry perspective. Economic Modelling , 37, 280-290.

[45] Mukherjee, T., \& Naka, A. (1995). Dynamic Relations Between Macroeconomic Variables And The Japanese Stock Market: An Application Of A Vector Error Correction Model. Journal of Financial Research, 18(2), 223-237.

[46] Nandha, M., \& Faff, R. (2008). Does oil move equity prices? A global view. Energy Economics, 30(3), 986-997.

[47] Narayan, P. K., \& Gupta, R. (2015). Has oil price predicted stock returns for over a century? Energy Economics, 48, 18-23.

[48] Narayan, P. K., \& Sharma, S. S. (2011). New evidence on oil price and firm returns. Journal of Banking \& Finance, 35, 3253-3262.

[49] Narayan, P. K., \& Sharma, S. S. (2014). Firm return volatility and economic gains: The role of oil prices. Economic Modelling, 38, 142151.

[50] Park, J., \& Ratti, R. (2008). Oil price shocks and stock markets in the U.S. and 13 European countries. Energy Economics, 30(5), 25872608.

[51] Ramos, S., \& Veiga, H. (2011). Risk factors in oil and gas industry returns: international evidence. Energy Economics, 33, 525-542.

[52] Sadorsky, P. (1999). Oil price shocks and stock market activity. Energy Economics, 21(5), 449-469.

[53] Sadorsky, P. (2001, 1). Risk factors in stock returns of Canadian oil and gas companies. Energy Economics, 23(1), 17-28.

[54] Scholtens, B., \& Yurtsever, C. (2012). Oil price shocks and European industries. Energy Economics, 34, 1187-1195.

[55] Sharpe, W. (1964). Capital Asset Prices: A Theory of Market Equilibrium under Considerations of Risk. The Journal of Finance, 19(3), 425-442.

[56] Siddiqui, R. (2004). Energy and Economic Growth in Pakistan. The Pakistan Development Review, 43(2), 175-200 .

[57] Wattanatorn, W., \& Kanchanapoom, T. (2012). Oil Prices and Profitability Performance: Sector Analysis. Procedia - Social and Behavioral Science, 40, 763-767.

[58] Xundi, D., Liyin, S., Saixing, Z., Jorge, O. J., \& Xiaoling, Z. (2010). Relationship between energy consumption and economic development in construction industry. Journal of Engineering, Design and Technology, 8(3), 257-273. 